\title{
Tıp fakültesi öğrencilerinin toplumsal cinsiyet rollerine ilişkin tutumları
}

\author{
Attitudes of medical students towards gender roles
}

\author{
Volkan Zeybek, Meliz Kurşun
}

Gönderilme tarihi: 08.10.2018

Kabul tarihi:18.03.2019

Özet

Amaç:Toplumsal cinsiyet eşitsizliğinin sonuçları arasında olan istenmeyen cinsel ilişki ve gebelik, sağlıksız düşükler, cinsel yolla bulaşan hastalıklar ve şiddet gibi sağlığı bozan etmenlerin sonuçlarıyla başa çıkma ve doğru yönlendirme konusunda sağlık çalışanlarının önemli sorumlulukları bulunmaktadır. Pamukkale Üniversitesi Tıp Fakültesi öğrencilerinin toplumsal cinsiyet rollerine ilişkin tutumları ve tutumlarını etkileyen faktörleri belirlemek amacıyla bu araştırma yapılmıştır.

Gereç ve Yöntem:Pamukkale Üniversitesi Tıp Fakültesi'nde öğrenim gören ve çalışmaya katılmayı kabul eden 276 kadın, 234 erkek, toplam 510 öğrenci araştırma grubunu oluşturmuştur. Veri toplama aracı olarak 38 sorudan ve 5 alt skaladan oluşan Toplumsal Cinsiyet Rolleri Tutum Ölçeği (TCRTÖ) (Cronbach Alfa Güvenirlik Katsayısı 0,92) ve sosyo-demografik özellikleri sorgulayan bilgi formu kullanılmıştır. Ölçeklerin değişken düzeyleri açısından normal dağılıma uygunluğu, örneklem sayısına göre "Kolmogorov-Smirnov" ve "ShapiroWilk" testleriyle belirlenmiştir. Verilerin değerlendirilmesinde ise "Student t-test" ve "Kruskal-Wallis H" istatistikleri yöntemi kullanılmıştır.

Bulgular:Öğrencilerin TCRTÖ toplam ve alt grup puan ortancaları ile cinsiyet, aile tipi, ailenin ekonomik durumu, kardeş sayısı, annenin eğitim durumu, babanın eğitim durumu, annenin çalışma durumu, doğum yeri ve uzun süre yaşadığı yer arasındaki farkın istatistiksel açıdan önemli olduğu saptanmıştır.

Sonuç:Çalışmamızın bulgularına göre tıp fakültesi öğrencilerinin toplumsal cinsiyet rollerine ilişkin tutumunu, sosyo-demografik özellikleri etkilemektedir. Mezuniyet öncesi tıp eğitiminde birinci sınıftan itibaren toplumsal cinsiyet eşitliğine duyarlı eğitim programlarının müfredata eklenerek yapılandırılmasının toplumsal cinsiyet eşitsizliğinden kaynaklanan sağlık problemlerinin çözülmesinde önemli olduğunu düşünmekteyiz.

Anahtar Kelimeler: Toplumsal cinsiyet, tıp fakültesi öğrencisi, tutum.

Zeybek V, Kurşun M. Tıp fakültesi öğrencilerinin toplumsal cinsiyet rollerine ilişkin tutumları. Pam Tıp Derg 2019;12:225-233.

\begin{abstract}
Purpose:Among the consequences of gender inequality, health workers have important responsibilities in dealing with the consequences of health-disrupting factors such as sexual assault and unintended pregnancy, unhealthy miscarriages, sexually transmitted diseases and violence. We aimed to detect the attitudes towards gender roles and predictors of such attitudes in medical school students affiliated at the Pamukkale University School of Medicine.

Materials and Methods:276 women, 234 men totally 510 students volunteered for the study. The Gender Roles Attitude Scale and data collection sheet were used in the current study. This scale consists of 38 Items. The highest point that may be received from the scale is 190 and the lowest is 38 . Receiving high points means having an egalitarian attitude. There are five sub-dimensions of the scale and they are; egalitarian gender, woman gender, gender at marriage, traditional gender and male gender roles. In statistical analyses of the data for the independent variables, the Student t- test and Kruskal Wallis Test were used.

Results:It was found that the difference between TCRT total and subgroup score median and gender, family type, family economic status, number of siblings, mother's education level, father's educational status, mother's working status, place of birth and place of residence were statistically significant.

Conclusion:According to the findings of our study, the socio-demographic characteristics affect the attitudes of the medical school students towards gender roles. We believe that it is important to solve the health problems arising from gender inequality by integrating the education programs that are sensitive to gender equality in the curriculum of undergraduate medical education from the first class.
\end{abstract}

Key Words: Gender, medical faculty student, attitude.

Zeybek V, Kurşun M. Attitudes of medical students towards gender roles. Pam Med J 2019;12:225-233.

Volkan Zeybek, Dr. Öğr. Üyesi. Pamukkale Üniversitesi Tıp Fakültesi Adli Tıp Anabilm Dalı, DENiZLi, e-posta: vzeybek@pau.edu.tr (orcid. org/0000-0002-8079-2671) (Sorumlu yazar)

Meliz Kurşun, Dr. Pamukkale Üniversitesi Tıp Fakültesi Adli Tıp Anabilim Dalı, DENiZLí, e-posta: mkursun@pau.edu.tr (orcid.org/0000-00033167-2267) 


\section{Giriş}

Cinsiyet ve toplumsal cinsiyet kavramları çoğu kez birbirine karıştırılmıştır. Oysaki "cinsiyet" kişinin kadın ya da erkek olarak gösterdiği genetik, fizyolojik ve biyolojik özellikleri, "toplumsal cinsiyet" kavramı ise, toplumun verdiği roller, görev ve sorumluluklar, toplumda eril düşünce tarafından oluşturulmuş algılar, beklentiler ile ilgili sosyoekonomik ve kültürel belirleyicileri olan bir kavramdır [1, 2].

Kadının ve erkeğin rolleri, aslında toplumsal cinsiyet temelinde tanımlanmış olmasına rağmen, biyolojik cinsiyet esasında tanımlanmış gibi düşünülmektedir. Bu anlayış, kadının erkekten farklı olduğu, ayrı roller oynaması, erkekten ayrı bir dünyada yaşaması gerektiği şeklindeki yargıların gelişmesine kaynaklık etmektedir. Bu nedenle toplumsal cinsiyet, erkek ya da kadınların birbirlerinden farklı olmalarına yol açan fiziksel niteliklere değil, erkeklik ve kadınlık hakkındaki toplum tarafından oluşturulmuş özelliklere göndermede bulunmaktadır [3, 4].

Toplumsal cinsiyet rollerinin toplumsal yaşama ilişkin yansımaları geleneksel ve eşitlikçi roller olarak kadın ve erkeklerin yaşamını farklı yönlerde şekillendirmektedir. Geleneksel roller içerisinde toplum tarafından kadına yüklenen roller; çocuk doğurma ve büyütme, temizlik yapma, bulaşık yıkama, yemek pişirme gibi ev işlerinden sorumlu olma, kendilerinden önce eşlerinin ve çocuklarının intiyaçlarını karşılama, onların mutluluğu ve rahatı için kendi isteklerinden ödün verme, iş hayatında aktif olmama gibi eşitlikçi olmayan sorumluluklardır. Erkeklere yüklenen geleneksel roller ise; ev dışında çalışma, aileleri için zorluklarla mücadele etme, evin geçiminden sorumlu olma, parasal kaynaklar üzerinde kontrol sahibi olma ve evin reisi olma gibi eşitlikçi olmayan sorumlulukları içermektedir. Toplum tarafından kadın ve erkeğe yüklenen eşitlikçi roller ise; aile, çalışma, evlilik ve eğitim yaşamında kadın ve erkeğin eşit olarak sorumlulukları paylaşmaları olarak belirtilmektedir $[5,6]$.

Toplumsal cinsiyet eşitsizliğinin net olarak ortaya çıktığı temel alanlardan biri sağlık hakkına erişim ve üreme sağlığı hakkı ile ilgilidir. Kadınlar için biyolojik cinsiyete bağı hastalık durumlarının dışında toplumsal cinsiyet eşitsizliğinin sonuçları olan istenmeyen cinsel ilişki ve gebelik, sağlıksız düşükler, cinsel yolla bulaşan hastalıklar ve şiddet gibi sağlığı bozan etmenler vardır [7]. Ayrıca, Kadına Yönelik Şiddet ve Aile İçi Şiddetin Önlenmesi ve Bunlarla Mücadeleye Dair Avrupa Konseyi Sözleşmesi'nde "Kadına karşı şiddetin yapısal özelliğinin toplumsal cinsiyete dayandığını ve kadına karşı şiddetin, kadınların erkeklere nazaran daha ast bir konuma zorlandıkları en önemli sosyal mekanizmalardan biri olduğunun bilincinde olunduğu" vurgulanmaktadır.

Toplumsal cinsiyet rollerinden köken alan kadına yönelik şiddetin sonuçlarıyla başa çıkma ve doğru yönlendirme konusunda sağlık çalışanlarının önemli sorumlulukları bulunmaktadır. Bu nedenle tıp eğitiminde, toplumsal cinsiyete duyarlı eğitim modellerinin uygulanmasının önemli olduğu belirtilmektedir [8-10]. Toplumsal cinsiyet rollerine ilişkin durum saptaması toplumsal cinsiyet duyarlı eğitim modellerinin geliştirilmesi için önemli bir basamaktır [2]. Toplumsal cinsiyete duyarlı tıp eğitimi sağlık hizmeti sunumunda kadından yana pozitif ayrımcılığı gözetir, eşitsizlikleri kapatmaya çalışır ve biyolojik-toplumsal cinsiyete dair süreçleri, durumları ve tedavileri kapsar [11].

Bu araştırmada Tıp Fakültesi'nde öğrenim gören öğrencilerin toplumsal cinsiyet rollerine ilişkin tutumları ve tutumlarını etkileyen demografik faktörleri belirlemek amaçlanmıştır.

\section{Gereç ve yöntem}

Bu araştırmanın evreni, 2017-2018 yılında Pamukkale Üniversitesi Tıp Fakültesi'nde eğitim gören 1203 öğrencinin tümü olarak planlanmıştır. Veri toplama formlarını eksiksiz bir şekilde doldurulmaması dışlama kriteri olarak belirlenmiştir. Ayrıca kayıtlı 128 dönem 6 öğrencisine dağıtılan formlardan yalnızca 10 'unun $(\% 7,8)$ eksiksiz doldurduğu anlaşıımış olup, bu sayı istatistiksel analiz sonuçlarını olumsuz etkileyeceği için dönem 6 öğrencilerinin verileri çalışmaya dahil edilmemiştir. Verilerin toplanması, ilk 3 dönem öğrencilerine probleme dayalı öğrenme oturumları öncesinde, dönem 4 ve 5 öğrencilerine sunum salonlarında sunum aralarında, araştırmanın amacı anlatılarak sözel gönüllü onamı alındıktan sonra formların dağıtılıp oturum ve sunumların ardından toplanması şeklinde gerçekleştirilmiştir. Toplam 1075 öğrenciden 510'u $(\% 47,4)$ dağıtılan veri 
toplama formlarını eksiksiz şekilde doldurmuştur. Formlar öğrencilere toplu halde dağıtıldığından, karşılıklı görüşme şeklinde uygulanmadığından planlanan sayıya ulaşılamamıştır.

Araştırmamız için Pamukkale Üniversitesi Girişimsel Olmayan Klinik Araştırmalar Etik Kurulu'ndan 17.01.2018 tarih ve 60116787020/4292 sayılı izin yazısı alınmıştır.

$\mathrm{Bu}$ araştırmada veri toplamak amacıyla öğrencilerin demografik özelliklerini belirlemek için hazırlanmış olan veri formu ile Zeyneloğlu tarafından geliştirilen "Toplumsal Cinsiyet Rolleri Tutum Ölçeği” (TCRTÖ) (Cronbach Alfa Güvenilirlik Katsayısı 0,92) kullanılmıştır [12].

Bu ölçek 38 madde ve beş alt boyut içermektedir. Alt boyutlar; bireylerin cinsiyet ayrımı yapmadan günlük yaşamdaki rol ve sorumlulukları eşit olarak paylaşmalarını ifade eden 8 maddelik 'eşitlikçi cinsiyet rolü', toplum tarafından kadına yüklenen rol ve sorumlulukları ifade eden 8 maddelik 'kadın cinsiyet rolü', toplum tarafından bireylere evlilik yaşamında yüklenen rol ve sorumlulukları ifaden 8 maddelik 'evlilikte cinsiyet rolü', toplum tarafından kadın ve erkeğe günlük hayatta yüklenen rol ve sorumlulukları ifade eden 8 maddelik 'geleneksel cinsiyet rolü' ve toplum tarafından erkeğe yüklenen rol ve sorumlulukları ifade eden 6 maddelik 'erkek cinsiyet rolü'nden oluşmaktadır. Ölçekte yer alan ifadeler arasında $1,4,8,12,13,18,19,20,21,22,26$ ve 27 nolu maddeler eşitlikçi tutum cümlelerini; 2, 3, 5, 6, 7 , $9,10,11,14,15,16,17,23,24,25,28,29,30$, $31,32,33,34,35,36,37$ ve 38 nolu maddeler ise geleneksel tutum cümlelerini içermektedir (Tablo 1). 5'li likert tipindeki bu ölçek, öğrencilerin toplumsal cinsiyet rollerine ilişkin eşitlikçi tutum cümlelerine; 'tamamen katılıyor' ise 5 puan, 'katılıyor' ise 4 puan, 'kararsız' ise 3 puan, 'katılmıyor' ise 2 puan, 'kesinlikle katılmıyor' ise 1 puan alacak şekilde puanlandırılmıştır. Bu puanlama sonucuna göre en yüksek puan '190', en düşük puan ise '38' olarak hesaplanmıştır. Ölçekten alınan en yüksek değer, öğrencinin toplumsal cinsiyet rollerine ilişkin 'eşitlikçi tutuma sahip' olduğunu, en düşük değer ise, öğrencinin toplumsal cinsiyet rollerine ilişkin 'geleneksel tutuma sahip' olduğunu göstermektedir.

Çalışmadan elde edilen veriler Statistical Package for Social Sciences (SPSS) 21.0 bilgisayar programında değerlendirilmiştir. Araştırmada öğrencilerin sosyo-demografik özellikleri bağımsız değişken, TCRTÖ puanları ise, bağımlı değişkenleri oluşturmaktadır. Verilerin değerlendirmesi için ortalama, standart sapma, yüzdelik dağılımlar, student-t testi ve Kruskal Wallis $\mathrm{H}$ analizi yapılmıştır. İstatistiksel testlerin anlamlılık düzeyi için $p<0,05$ değeri kabul edilmiştir.

\section{Bulgular}

Katılımcıların \%24,3'ü dönem 1, \%22,4'ü dönem 2, \%23,3 dönem 3, \%9,8'i dönem 4, \%20 ,2'si dönem 5 öğrencisiydi ve yaş ortalamaları $21,2 \pm 2,33$ idi. Araştırma grubunun \%54,1'i kadın öğrencilerden oluşmaktaydı. \%64,9'unun en uzun süre yaşadığı yer ve \%63,1'inin doğduğu yer şehir merkezidir. Ebeveyn eğitim düzeyleri incelendiğinde annelerin \%24,9'unun, babaların \%14,9'unun ilkokul ve altında eğitime sahip olduğu saptanmıştır. Öğrencilerin annelerinin \%44,7'si herhangi bir işte çalışmakta veya emeklidir. Ailesinin gelir düzeyi için öğrencilerin \%53,5'i 1500- 5000TL şeklinde yanıt vermiştir (Tablo 2). TCRTÖ'ne verilen yanıtlara göre puan ortalamaları Tablo 1'de sunulmuştur.

Tablo 3'te öğrencilerin "Toplumsal Cinsiyet Rolleri Tutum" ölçeğinden aldıkları toplam ve alt boyut puanlarına ait tanımlayıcı istatistikler yer almaktadır. "Toplumsal Cinsiyet Rolleri Tutum" ölçeğinden elde edilen toplam puan $162,85 \pm 21,81$ olup, öğrencilerin aldığı en düşük puan 38 ve en yüksek puan ise 190 olarak belirlenmiştir. Öğrencilerin toplumsal cinsiyet rollerine ilişkin tutumlarının eşitlikçi yönde olduğu görülmektedir.

Cinsiyet, anne eğitim düzeyi ve baba eğitim düzeyi değişkenleri arasında TCRTÖ toplam puan ortalamaları ve tüm alt boyut puan ortalamaları arasındaki fark istatistiksel olarak anlamlı bulunmuştur. Ayrıca annenin çalışması, en uzun süre yaşanılan yer, doğum yeri, aile gelir düzeyi ve kardeş sayısı değişkenleri arasında TCRTÖ ve bazı alt boyut puan ortalamaları arasındaki fark istatistiksel olarak anlamlı bulunmuştur (Tablo 4). Öğrencilerin kayıtlı oldukları dönem, babanın çalışma durumu, aile tipi, mezun olunan lise türü değişkenleri arasında istatistiksel olarak anlamlı bir fark saptanmamıştır. 
Tablo 1. Öğrencilerin TCRTÖ maddelerine yanıtlarının dağıımı (\%).

\begin{tabular}{|c|c|}
\hline Tutum Ífadeleri & ortalama $\pm S S$ \\
\hline 1. Kızlar, ekonomik bağımsızlıklarını kazandıklarında ailelerinden ayrı yaşayabilmelidir. (K) & $4,31 \pm 0,98$ \\
\hline *2. Erkeğin evde her dediği yapılmalıdır. (Ev) & $4,53 \pm 0,83$ \\
\hline *3. Kadının yapacağı meslekler ile erkeğin yapacağı meslekler ayrı olmalıdır. (G) & $3,88 \pm 1,14$ \\
\hline 4. Evilikte çocuk sahibi olma kararını eşler birlikte vermelidir. (Eş) & $4,76 \pm 0,73$ \\
\hline *5. Bir genç kızın evleneceği kişiyi seçmesinde son sözü baba söylemelidir. (K) & $4,3 \pm 0,91$ \\
\hline *6. Kadının erkek çocuk doğurması onun değerini artıır. (Ev) & $4,76 \pm 0,68$ \\
\hline *7. Kadının doğurganlık özelliği nedeniyle, iş başvurularında erkekler tercih edilmelidir. (G) & $4,57 \pm 0,85$ \\
\hline 8. Ailede ev işleri, eşler arasında eşit paylaşılmalıdır. (Eş) & $4,36 \pm 0,97$ \\
\hline *9. Kadının yaşamıyla ilgili kararları kocası vermelidir. (Ev) & $4,58 \pm 0,78$ \\
\hline $\begin{array}{l}\text { *10. Kadınlar kocalarıyla anlaşamadıkları konularda tartışmak yerine susmayı tercih etmelidir. } \\
\text { (Ev) }\end{array}$ & $4,44 \pm 0,91$ \\
\hline *11. Bir genç kız, evlenene kadar babasının sözünü dinlemelidir. (G) & $3,54 \pm 1,22$ \\
\hline 12. Ailenin maddi olanaklarından kız ve erkek çocuk eşit yararlanmalıdır. (Eş) & $4,69 \pm 0,75$ \\
\hline 13. Çalışma yaşamında kadınlara ve erkeklere eşit ücret ödenmelidir. (Eş) & $4,52 \pm 0,96$ \\
\hline *14. Bir erkeğin karısını aldatması normal karşılanmalıdır. (Ev) & $4,83 \pm 0,62$ \\
\hline *15. Kadının çocuğu olmuyorsa erkek tekrar evlenmelidir. (Ev) & $4,61 \pm 0,81$ \\
\hline *16. Kadının temel görevi anneliktir. (K) & $3,88 \pm 1,25$ \\
\hline *17. Evin reisi erkektir. (G) & $4,00 \pm 1,34$ \\
\hline 18. Dul kadın da dul erkek gibi yalnız başına yaşayabilmelidir. (Eş) & $4,54 \pm 0,81$ \\
\hline 19. Bir genç kızın, flört etmesine ailesi izin vermelidir. (K) & $3,86 \pm 1,15$ \\
\hline 20. Ailede kararları eşler birlikte almalıdır. (Eş) & $4,75 \pm 0,63$ \\
\hline 21. Bir kadın akşamları tek başına sokağa çıkabilmelidir. (K) & $4,51 \pm 0,83$ \\
\hline 22. Eşler boşandığında mallar eşit paylaşıımalıdır. (Eş) & $4,40 \pm 0,99$ \\
\hline *23. Kız bebeğe pembe, erkek bebeğe mavi renkli giysiler giydirilmelidir. (G) & $3,86 \pm 1,07$ \\
\hline *24. Erkeğin en önemli görevi evini geçindirmektir. (G) & $3,46 \pm 1,34$ \\
\hline *25. Erkeğin maddi gücü yeterliyse kadın çalışmamalıdır. (G) & $4,15 \pm 1,05$ \\
\hline 26. Evlilikte, kadın istemediği zaman cinsel ilişkiyi reddetmelidir. (Ev) & $4,32 \pm 0,99$ \\
\hline 27. Mesleki gelişme fırsatlarında kadınlara ve erkeklere eşit haklar tanınmalıdır. (Eş) & $4,66 \pm 0,74$ \\
\hline *28. Evlilikte erkeğin öğrenim düzeyi kadından yüksek olmalıdır. (Er) & $4,21 \pm 1,01$ \\
\hline *29. Bir kadın cinsel ilişkiyi evlendikten sonra yaşamalıdır. (K) & $3,14 \pm 1,36$ \\
\hline *30. Ailede erkek çocuğun öğrenim görmesine öncelik tanınmalıdır. (Er) & $4,52 \pm 0,90$ \\
\hline *31. Erkeğin evleneceği kadın bakire olmalıdır. (K) & $3,77 \pm 1,28$ \\
\hline *32. Alışveriş yapma, fatura ödeme gibi ev dışı işlerle erkek uğraşmalıdır. (G) & $3,77 \pm 1,19$ \\
\hline *33. Erkekler statüsü yüksek olan mesleklerde çalışmalıdır. (Er) & $3,93 \pm 1,12$ \\
\hline *34. Ailede kazancın nasıl kullanılacağına erkek karar vermelidir. (Er) & $4,32 \pm 0,93$ \\
\hline *35. Bir erkek gerektiğinde karısını dövmelidir. (Er) & $4,84 \pm 0,60$ \\
\hline *36. Evlilikte gebelikten korunmak sadece kadının sorumluluğudur. (Ev) & $4,73 \pm 0,66$ \\
\hline *37. Bir kadın hastaneye gittiğinde kadın doktora muayene olmalıdır. (K) & $4,47 \pm 0,90$ \\
\hline *38. Evlilikte erkeğin yaşı kadından büyük olmalıdır. (Er) & $3,88 \pm 1,16$ \\
\hline
\end{tabular}

* Tutum ölçeği değerlendirilirken ankette bulunan negatif yönlü geleneksel tutum ifadeleri tersine puanlandırıldı. Eş: Eşitlikçi cinsiye rolü $\mathrm{K}$ : Kadın cinsiyet rolü Ev: Evililikte cinsiyet rolü G: Geleneksel cinsiyet rolü Er: Erkek cinsiyet rolü 
Tablo 2. Öğrencilerin sosyo-demografik özellikleri.

\begin{tabular}{|c|c|c|}
\hline & Sayı (n) & $(\%)$ \\
\hline \multicolumn{3}{|l|}{ Cinsiyet } \\
\hline Kadın & 276 & 54,1 \\
\hline Erkek & 234 & 45,9 \\
\hline \multicolumn{3}{|l|}{ Anne Eğitim Düzeyi } \\
\hline İlkokul ve altı & 127 & 24,9 \\
\hline Ortaokul- lise & 194 & 38,0 \\
\hline Üniversite & 189 & 37,1 \\
\hline \multicolumn{3}{|l|}{ Baba eğitim düzeyi } \\
\hline İlkokul ve altı & 76 & 14,9 \\
\hline Ortaokul- lise & 153 & 30,0 \\
\hline Üniversite & 281 & 55,1 \\
\hline \multicolumn{3}{|l|}{ Anne çalışma durumu } \\
\hline Çalışıyor/emekli & 228 & 44,7 \\
\hline Çalışmıyor/ev hanımı & 282 & 55,3 \\
\hline \multicolumn{3}{|l|}{ Baba çalışma durumu } \\
\hline Çalışıyor/emekli & 501 & 98,2 \\
\hline Çalışmıyor & 9 & 1,8 \\
\hline \multicolumn{3}{|l|}{ Doğum yeri } \\
\hline Şehir merkezi & 322 & 63,1 \\
\hline Köy/ilçe & 188 & 36,9 \\
\hline \multicolumn{3}{|c|}{ En uzun süre yaşadığı yer } \\
\hline Şehir merkezi & 331 & 64,9 \\
\hline Köy/ilçe & 179 & 35,1 \\
\hline \multicolumn{3}{|l|}{ Aile geliri } \\
\hline $0-1600$ tl & 30 & 5,9 \\
\hline $1600-5000 t$ & 273 & 53,5 \\
\hline $5000-10000 t l$ & 183 & 35,9 \\
\hline 10000tl ve üzeri & 24 & 4,7 \\
\hline
\end{tabular}

Tablo 3. Öğrencilerinin toplumsal cinsiyet rolleri tutum ölçeği sonuçları.

\begin{tabular}{lll}
\hline Alt Boyutlar & OrtıSS* & Min-Max \\
\hline Eşitlikçi Cinsiyet Rolü & $36,68 \pm 4,50$ & $8-40$ \\
Kadın Cinsiyet Rolü & $32,32 \pm 5,94$ & $8-40$ \\
Evilikte Cinsiyet Rolü & $36,83 \pm 4,49$ & $8-40$ \\
Geleneksel Cinsiyet Rolü & $31,27 \pm 6,37$ & $8-40$ \\
Erkek Cinsiyet Rolü & $25,72 \pm 4,09$ & $6-30$ \\
Toplam & $162,85 \pm 21,81$ & $38-190$ \\
\hline
\end{tabular}


Tablo 4. Öğrencilerin toplumsal cinsiyet rolleri tutumlarının demografik özelliklere göre analiz sonuçları.

\begin{tabular}{|c|c|c|c|c|c|c|c|c|}
\hline & & $n$ & Toplam ort土SS & Eşitlikçi & Kadın & Evlilikte & Geleneksel & Erkek \\
\hline \multirow[t]{3}{*}{ Cinsiyet } & Kadın & 276 & $169,9 \pm 16,12$ & $37,8 \pm 3,2$ & $33,6 \pm 5,2$ & $38,3 \pm 2,6$ & $33,3 \pm 5,3$ & $26,7 \pm 3,3$ \\
\hline & Erkek & 234 & $154,4 \pm 24,4$ & $35,2 \pm 5,2$ & $30,7 \pm 6,3$ & $35,1 \pm 5,5$ & $28,8 \pm 6,6$ & $24,5 \pm 4,5$ \\
\hline & & & $p<0,001^{*}$ & $p<0,001^{*}$ & $p<0,001^{*}$ & $p<0,001^{*}$ & $p<0,001^{*}$ & $p<0,001^{*}$ \\
\hline \multirow{3}{*}{$\begin{array}{l}\text { Anne } \\
\text { çalışma } \\
\text { durumu }\end{array}$} & Çalışıyor & 282 & $160,4 \pm 20,1$ & $36,4 \pm 3,9$ & $31,2 \pm 6,1$ & $36,7 \pm 3,8$ & $30,5 \pm 6,1$ & $25,4 \pm 3,8$ \\
\hline & Çalışmıyor & 228 & $165,8 \pm 23,4$ & $36,9 \pm 5,1$ & $33,6 \pm 5,5$ & $37,0 \pm 5,1$ & $32,1 \pm 6,4$ & $26,0 \pm 4,3$ \\
\hline & & & $p: 0,006^{*}$ & $p: 0,225$ & $p:<0,001^{*}$ & $p: 0,469$ & $p: 0,003^{*}$ & $p: 0,114$ \\
\hline \multirow[t]{3}{*}{ Doğum yeri } & $\begin{array}{l}\text { Şehir } \\
\text { merkezi }\end{array}$ & 322 & $165,1 \pm 20$ & $37,1 \pm 4,0$ & $33,0 \pm 5,5$ & $37,2 \pm 3,8$ & $31,8 \pm 6,1$ & $25,9 \pm 3,8$ \\
\hline & İlçe/Köy & 188 & $158,9 \pm 24$ & $36,0 \pm 5,1$ & $31,1 \pm 6,3$ & $36,1 \pm 5,3$ & $30,3 \pm 6,6$ & $25,3 \pm 4,4$ \\
\hline & & & $p: 0,002^{*}$ & $p: 0,012^{*}$ & $p: 0,001^{*}$ & $p: 0,007^{*}$ & $\mathrm{p}: \mathbf{0 , 0 1 4 ^ { * }}$ & $p: 0,102$ \\
\hline \multirow[t]{3}{*}{$\begin{array}{l}\text { En uzun } \\
\text { süre } \\
\text { yaşadığı yer }\end{array}$} & $\begin{array}{l}\text { Şehir } \\
\text { merkezi }\end{array}$ & 331 & $164,9 \pm 21,5$ & $36,9 \pm 4,4$ & $33,0 \pm 5,7$ & $37,1 \pm 4,3$ & $31,8 \pm 6,2$ & $25,9 \pm 4,0$ \\
\hline & İlçe/Köy & 179 & $158,9 \pm 21,7$ & $36,1 \pm 4,6$ & $30,7 \pm 6,0$ & $36,2 \pm 4,7$ & $30,1 \pm 6,4$ & $25,3 \pm 4,0$ \\
\hline & & & $p: 0,003^{*}$ & $p: 0,055$ & $p<0,001^{*}$ & $p: 0,05$ & $p: 0,004^{*}$ & $p: 0,132$ \\
\hline \multirow[t]{4}{*}{$\begin{array}{l}\text { Anne eğitim } \\
\text { durumu }\end{array}$} & $\begin{array}{l}\text { İlkokul ve } \\
\text { altı (1) }\end{array}$ & 127 & $157,7 \pm 21,0$ & $36,0 \pm 4,4$ & $30,5 \pm 6,1$ & $36,3 \pm 4,2$ & $29,8 \pm 6,6$ & $24,9 \pm 4,1$ \\
\hline & $\begin{array}{l}\text { Ortaokul/ } \\
\text { Lise (2) }\end{array}$ & 194 & $161,7 \pm 20,5$ & $36,3 \pm 4,4$ & $31,8 \pm 5,8$ & $36,8 \pm 4,0$ & $30,9 \pm 6,2$ & $25,7 \pm 3,5$ \\
\hline & $\begin{array}{l}\text { Üniversite } \\
\text { (3) }\end{array}$ & 189 & $167,4 \pm 22,7$ & $37,3 \pm 4,5$ & $34,0 \pm 5,5$ & $37,2 \pm 5,0$ & $32,6 \pm 6,0$ & $26,1 \pm 4,4$ \\
\hline & & & $p<0,001^{* *}$ & $\begin{array}{l}p: 0,002^{* *} \\
(1-3)(2-3)\end{array}$ & $\begin{array}{l}p<0,001^{* *} \\
(1-3)(2-3)\end{array}$ & $\begin{array}{l}p: 0,001^{* *} \\
(1-3)(2-3)\end{array}$ & $\begin{array}{l}p<0,001^{* *} \\
(1-3)(2-3)\end{array}$ & $\begin{array}{c}p: 0,003^{\text {** }} \\
(1-3)\end{array}$ \\
\hline \multirow[t]{4}{*}{$\begin{array}{l}\text { Baba eğitim } \\
\text { durumu }\end{array}$} & $\begin{array}{l}\text { Illkokul ve } \\
\text { altı (1) }\end{array}$ & 76 & $157,0 \pm 19,9$ & $36,0 \pm 4,6$ & $30,4 \pm 6,4$ & $36,4 \pm 3,5$ & $29,3 \pm 6,5$ & $24,7 \pm 3,9$ \\
\hline & $\begin{array}{l}\text { Ortaokul/ } \\
\text { Lise (2) }\end{array}$ & 153 & $160,5 \pm 21,0$ & $36,2 \pm 4,2$ & $31,7 \pm 5,8$ & $36,4 \pm 4,7$ & $30,6 \pm 6,1$ & $25,4 \pm 4,2$ \\
\hline & $\begin{array}{l}\text { Üniversite } \\
\text { (3) }\end{array}$ & 281 & $165,6 \pm 22,3$ & $37,0 \pm 4,5$ & $33,1 \pm 5,7$ & $37,1 \pm 4,5$ & $32,1 \pm 6,3$ & $26,1 \pm 4,0$ \\
\hline & & & $\begin{array}{l}p<0,001^{* *} \\
(1-3)(2-3)\end{array}$ & $\begin{array}{l}p: 0,013^{* *} \\
(1-3)(2-3)\end{array}$ & $\begin{array}{l}p<0,001^{* *} \\
(1-3)(2-3)\end{array}$ & $\begin{array}{l}p: 0,003^{* *} \\
(1-3)(2-3)\end{array}$ & $\begin{array}{l}p: 0,001^{* *} \\
(1-3)(2-3)\end{array}$ & $\begin{array}{l}p: 0,006^{* *} \\
(1-3)(2-3)\end{array}$ \\
\hline \multirow[t]{5}{*}{$\begin{array}{l}\text { Aile } \\
\text { gelir düzeyi }\end{array}$} & $\begin{array}{l}0-1600 \mathrm{TL} \\
\text { (1) }\end{array}$ & 30 & $153,5 \pm 23,0$ & $35,4 \pm 4,4$ & $29,2 \pm 7,4$ & $35,2 \pm 3,9$ & $28,9 \pm 6,8$ & $24,6 \pm 4,2$ \\
\hline & $\begin{array}{l}1600-5000 \\
\text { TL (2) }\end{array}$ & 273 & $162,3 \pm 21,2$ & $36,6 \pm 4,3$ & $31,7 \pm 5,8$ & $37,0 \pm 4,4$ & $31,2 \pm 6,1$ & $25,6 \pm 4,1$ \\
\hline & $\begin{array}{l}5000-10000 \\
\text { TL (3) }\end{array}$ & 183 & $165,0 \pm 21,5$ & $36,9 \pm 4,6$ & $33,4 \pm 5,4$ & $36,9 \pm 4,5$ & $31,8 \pm 6,3$ & $25,9 \pm 3,8$ \\
\hline & $\begin{array}{l}>10000 \mathrm{TL} \\
(4)\end{array}$ & 24 & $163,2 \pm 26,1$ & $36,7 \pm 4,5$ & $34,1 \pm 6,0$ & $36,0 \pm 5,4$ & $30,8 \pm 7,8$ & $25,4 \pm 5,0$ \\
\hline & & & $\begin{array}{c}p: 0,026^{* *} \\
(1-3)\end{array}$ & $p: 0,157$ & $\begin{array}{c}p<0,001^{* *} \\
(1-3)(1-4)(2-3)\end{array}$ & $\begin{array}{l}p: 0,018^{* *} \\
(1-2)(1-3)\end{array}$ & $p: 0,149$ & $p: 0,406$ \\
\hline \multirow[t]{6}{*}{$\begin{array}{l}\text { Kardeş } \\
\text { sayısı }\end{array}$} & Yok (1) & 70 & $167,4 \pm 20,0$ & $37,4 \pm 3,7$ & $33,6 \pm 5,4$ & $37,3 \pm 4,1$ & $32,7 \pm 5,7$ & $26,3 \pm 3,9$ \\
\hline & $1(2)$ & 201 & $165,2 \pm 21,5$ & $36,7 \pm 4,7$ & $33,4 \pm 5,5$ & $36,9 \pm 4,6$ & $31,8 \pm 6,2$ & $26,1 \pm 3,8$ \\
\hline & $2(3)$ & 135 & $160,5 \pm 23,5$ & $36,4 \pm 4,7$ & $31,6 \pm 5,8$ & $36,5 \pm 5,0$ & $30,5 \pm 6,6$ & $25,2 \pm 4,6$ \\
\hline & $3(4)$ & 76 & $160,3 \pm 19,3$ & $36,3 \pm 4,1$ & $31,1 \pm 5,8$ & $36,9 \pm 3,4$ & $30,6 \pm 6,1$ & $25,3 \pm 3,5$ \\
\hline & $\begin{array}{l}4 \text { ve üzeri } \\
\text { (5) }\end{array}$ & 28 & $152,5 \pm 21,3$ & $36,2 \pm 4,3$ & $27,5 \pm 7,4$ & $35,8 \pm 3,7$ & $28,3 \pm 6,7$ & $24,5 \pm 4,5$ \\
\hline & & & $\begin{array}{l}p<0,001^{* *} \\
(1-5)(2-5)\end{array}$ & $p: 0,378$ & $\begin{array}{c}p<0,001^{* *} \\
(1-5)(2-5)(2-4)\end{array}$ & $p: 0,07$ & $\begin{array}{c}p: 0,013^{* *} \\
(1-5)\end{array}$ & $p: 0,068$ \\
\hline
\end{tabular}

*Student $\mathrm{t}$ test kullanılmıştır ve istatistiksel olarak anlamlıdır. **Kruskal Wallis H kullanılmıştır ve istatistiksel olarak anlamlıdır. 


\section{Tartışma}

Bu çalışmada katılımcıların TCRTÖ'nden aldıkları toplam ve 5 alt boyuttan aldıkları puan ortalamaları (Tablo 3) göz önüne alındığında, katılımcıların genel olarak eşitlikçi toplumsal cinsiyet rol tutumlarına sahip oldukları düşünülmüştür. Sağlık çalışanları ve sağlık bilimleri ile ilgili bölümlerin öğrencileri ile yapılan toplumsal cinsiyet rol tutumlarının değerlendirildiği çalışmalarda da katılımcıların eşitlikçi tutumlara sahip oldukları görülmektedir [6, 13-15]. Araştırma sonuçları arasında, çalışmanın yapıldığı bölge ve örneklem grubunun özelliğine bağlı olarak farklılıklar olduğu görülmektedir.

Toplumsal cinsiyet eşitsizliği, ülkemizde ve dünyada farklı boyutlarda yaşanan bir sorundur. $\mathrm{Bu}$ aşamada topluma sağlık hizmeti sunan bireylerin eşitlikçi bakış açısına sahip olmaları, sağlık hizmeti sunarken eşitlikçi yaklaşımlarda bulunmaları ve tüm uygulamalara "toplumsal cinsiyet eşitliği” perspektifinden bakabilmeleri gerekmektedir. Ayrıca sağlık çalışanları toplumsal cinsiyet rollerine ilişkin tutumları eşitlikçi bir biçimde şekillendirilerek topluma kazandırılmasında önemli sorumlulukları olan kişilerdir [4, 6, 16, 17]. Sağlık bilimleri ile ilgili fakültelerde öğrencilerin toplumsal cinsiyet rollerine ilişkin tutum ve algı düzeylerine yönelik çalışmalar ve toplumsal cinsiyet duyarlı tıp eğitimine yönelik çalışmalar yapıldığı görülmektedir. Literatüre bakıldığında; herhangi bir üniversitede Tıp Fakültesi'nde okuyan tüm öğrencileri kapsayan toplumsal cinsiyet rollerine ilişkin tutum ve bu tutumları etkileyen faktörlerin değerlendirildiği çalışmanın çok az olduğu görülmektedir. Bu çalışmada, Tıp Fakültesi öğrencilerinin toplumsal cinsiyet rollerine ilişkin tutumları ile bunları etkileyen bir takım demografik değişkenler açısından farklılık gösterip göstermediği istatistiksel analiz teknikleriyle incelenmiştir.

Araştırmanın temel değişkenleri olan toplumsal cinsiyet rolü tutumları, sosyo demografik özelliklere göre incelenmiş; cinsiyet, anne- baba eğitim düzeyi, annenin çalışma durumu, ekonomik durum, kardeş sayısı, doğum yeri ve en uzun süre yaşadığı yer değişkenleri ile anlamlı ilişkiler bulunmuştur. Bu sonuçlar Türkiye'de üniversite öğrencileri ve daha ileri yaş katılımcılarla yapılan çalışmaların sonuçlarıyla paralellik göstermektedir [18, 19].
Öğrencilerin TCRTÖ'nden aldıkları toplam ve tüm alt boyut puanlarına göre cinsiyetler arasındaki fark karşılaştırıldığında anlamlı olarak kadınların erkeklere göre daha eşitlikçi tutuma sahip oldukları ortaya çıkmıştır $(p<0,001)$. Üniversite öğrencileri ile yapılan çalışmalarda da benzer sonuçlar bulunmuştur $[5,6,15,16$, 20]. Cinsiyetler arasındaki bu anlamlı fark; ataerkil toplum yapısı içinde yetişen kadının sosyal ve çalışma hayatında var olabilmek için daha eşitlikçi rol tutumlarına intiyaç duyması, erkeğin ise toplumun geleneksel rollere ilişkin dayatmalarının kendi yararlarına olması ile açıklanabilir.

TCRTÖ'nden alınan toplam ve tüm alt boyut puanlarına göre anne ve baba eğitim düzeyi arasındaki farklar karşılaştırıldığında üniversite mezunu annesi ve/veya babası olanların istatistiksel olarak anlamlı biçimde daha eşitlikçi tutuma sahip olduğu görülmüştür. Benzer şekilde aile gelir düzeyi yüksek olan ve annesi çalışan öğrencilerin toplamda ve kadın cinsiyet rolü ile evlilikte cinsiyet rolü alt boyutlarında istatistiksel olarak daha eşitlikçi tutuma sahip oldukları, kardeş sayısı daha az olan öğrencilerin toplamda ve kadın cinsiyet rolü ile geleneksel cinsiyet rolü alt boyutlarında istatistiksel olarak daha eşitlikçi tutuma sahip oldukları görülmüştür. Türkiye'deki kadınların eğitim düzeyi ile iş gücüne katılım oranları arasında pozitif bir ilişki görülmektedir. Eğitim durumu ve yoksulluk arasında ters orantı olduğunu gösteren çalışmalar bulunmaktadır. Eğitim durumu yükseldikçe yoksulluk oranları önemli ölçüde azalmaktadır. Eğitim; iş gücünün verimliliğini arttırmakta, aile gelirini yükselterek yoksulluğun azaltılmasını sağlamakta, sağlık ve beslenmeyi geliştirmekte, doğurganlığı azaltmakta ve dolayısıyla bir ülkenin toplumsal ve siyasal gelişimine katkıda bulunmaktadır [21]. Bu nedenlerle ebeveyn eğitim düzeyi ve gelir düzeyi yüksek, kardeş sayısı az olan ve annenin çalıştığı ailelerde yetişen öğrencilerin eşitlikçi tutma sahip oldukları düşünülmüştür.

Kentte doğan öğrencilerin toplamda ve erkek cinsiyet rolü alt boyutu hariç diğer alt boyutlarda ve kentte uzun süre yaşamış öğrencilerin toplamda ve kadın cinsiyet rolü ile geleneksel cinsiyet rolü alt boyutlarında istatistiksel olarak daha eşitlikçi tutuma sahip oldukları görülmüştür. Aile ve Sosyal Politikalar Bakanlığı'nın aile içi şiddet ile ilgili yaptığı bir çalışmada şiddet düzeyinin yerleşim yerine göre önemli bir 
farklılık göstermemesine rağmen, dikkat çekici bir bulgu olarak toplum cinsiyet rollerine ilişkin tutumlar açısından kadının yaşadığı yerleşim yeri önemli bir farklılık yarattığı ayrıca kadınların refah düzeyine göre toplumsal cinsiyet rollerine ilişkin tutumlarda görülen farklılaşma yine şiddet düzeyindeki farklılaşmadan daha belirgin olduğu ifade edilmektedir [22].

Çalışmamızda her ne kadar öğrencilerin eşitlikçi tutuma sahip oldukları görülmüş olsa da sınıflar arasında anlamlı bir fark olmaması fakültedeki eğitimin toplumsal cinsiyet rollerine ilişkin tutumlara olumlu etkisinin olmadığını düşündürmektedir. Yapılan bir çalışmada verilen eğitimin katıımcıların toplumsal cinsiyet algılarının ortalamalarını ve toplumsal cinsiyet rollerine ilişkin tutumlarında anlamlı derecede artırdığı ve cinsiyet değişkeni açısından incelendiğinde eğitimin erkeklerin ortalamalarını çok daha fazla yükselttiği gösterilmiştir [23]. Tıp eğitiminde toplumsal cinsiyet eşitliğine duyarlı programların kullanılmasının öğrencilerde bu konuda pozitif farkındalık yaratacağı ve mezuniyet sonrası hayatlarında da toplumsal cinsiyet eşitsizliğinden kaynaklanan sağlık sorunlarında çözüm üretebilecekleri belirtilmektedir [9, 24]. Kadına yönelik aile içi Şiddetle Mücadele Ulusal Eylem Planı'nda toplumsal cinsiyet eşitliği ve kadına yönelik aile içi şiddet konularına eğitim, hukuk, tıp, iletişim ve diğer ilgili fakültelerin lisans programlarında yer verilmesi belirtilmektedir. Mezuniyet öncesi tıp eğitimi ulusal çekirdek eğitim programında da toplumsal cinsiyet ve sağlık başlığı bulunmaktadır.

Tüm bunların yanında araştırmamızın bazı kısıtlılıklarının da bulunduğunu bildirmekte yarar görmekteyiz. Çalışmamızda hedeflenen katılımcı sayısına ulaşılamamış olup özellikle dönem 6 öğrencilerinde katılım \%7.8 gibi çok düşük seviyede olması nedeniyle dönem 6 verileri çalışmaya dahil edilmemiştir. Bulgular, ilk beş döneme kayıtlı 510 (\%47.4) öğrencinin verilerinden elde edilmiştir. Benzer çalışmalara bakıldığında ulaşılan katııımcı sayısının yeterli olduğu düşünülmekle beraber ileride daha kapsamlı katılımcı sayısına ulaşılarak yapılacak çalışmalarla verilerimizin desteklenmesi uygun olacaktır.

Sonuç olarak, mezuniyet öncesi tıp eğitiminde birinci sınıftan itibaren toplumsal cinsiyet eşitliğine duyarlı eğitim programlarının müfredata eklenerek yapılandırılmasının toplumsal cinsiyet eşitsizliğinden kaynaklanan sağlık problemlerinin çözülmesinde önemli olduğunu düşünmekteyiz. Ayrıca öğrencilere eğitim veren akademisyenleri de kapsayan daha geniş çaplı çalışmalar planlanarak bölgesel farkıııklar ortaya çıkarıımalıdır.

Çıkar İlişkisi: Yazarlar çıkar ilişkisi olmadığını beyan eder.

\section{Kaynaklar}

1. T.C. Başbakanlık Kadının Statüsü Genel Müdürlüğü, Toplumsal Cinsiyet Eşitliği Ulusal Eylem Planı, 2008.

2. Varol ZS, Çiçeklioğlu M, Taner Ş. Bir Tıp Fakültesi birinci sınıf öğrencilerinde toplumsal cinsiyet algı düzeyi ve ilişkili faktörlerin değerlendirilmesi. Ege Tıp Derg 2016;55:122-128. https://doi.org/10.19161/etd.344208

3. Altınova H, Duyan V. Toplumsal cinsiyet algısı ölçeğinin geçerlik güvenirlik çalışması. Toplum Ve Sosyal Hizmet 2013;24:9-22.

4. Akın A, Demirel S. Toplumsal cinsiyet kavramı ve sağlığa etkileri. C.U. Tıp Fakültesi Derg Halk Sağlığı Özel Eki 2003;25:73-82.

5. Zeyneloğlu S. Ankara'da hemşirelik öğrenimi gören üniversite öğrencilerinin toplumsal cinsiyet rollerine ilişkin tutumları. Doktora Tezi. Hacettepe Üniversitesi Sağlık Bilimleri Enstitüsü, Ankara, 2008.

6. Atış F. Ebelik/Hemşirelik 1. ve 4. sınıf öğrencilerinin toplumsal cinsiyet rollerine ilişkin tutumlarının belirlenmesi. Yayınlanmamış Yüksek Lisans Tezi. Çukurova Üniversitesi Sağlık Bilimleri Enstitüsü Ebelik Anabilim Dalı, Adana, 2010.

7. World Health Organization Gender and health: Technical paper. Available at: http://www.who.int/iris/ handle/10665/63998. Erişim tarihi 14 Ağustos 2018.

8. Kandemirci D, Kağnıcı DY. Kadına yönelik aile içi şiddetle baş etme: çok boyutlu bir inceleme. Türk Psikoloji Yazıları 2014;17:1-12.

9. Dielissen $P$, Verdonk $P$, Wieringa-de Waard M, Bottema $B$, Lagro-Janssen $T$. The effect of gender medicine education in GP training: a prospective cohort study. Perspect Med Educ 2014;3:343-356. https://doi. org/10.1007/s40037-014-0122-3

10. World Health Organisation (WHO). Consensus statement on gender and medical education. Geneva: 2006.

11. Verdonk P, Benschop YW, De Haes HCJ, LagroJanssen TL. Medical students' gender awareness. Sex Roles 2008;58:222-234. https://doi.org/10.1007/ s11199-007-9326-x

12. Zeyneloğlu S, Terzioğlu F. Development and psychometrıc propertıes gender roles attitude scale. $\mathrm{H}$. Ü. Eğitim Fakültesi Derg 2011;40:409-420. 
13. Direk N, Irmak B. Dokuz Eylül Üniversitesi Tıp Fakültesi öğrencilerinde toplumsal cinsiyet rollerine yönelik tutumlar. DEÜ Tıp Fakültesi Derg, 2017;31:121-128.

14. Seyitoglu $D C ̧$, Güneş $G$, Baran $A$. İnönü Üniversitesi Tıp Fakültesi öğrencilerinin toplumsal cinsiyet rollerine ilişkin tutumlarının belirlenmesi. MedScience 2016;5:102-116. https://doi.org/10.5455/ medscience.2015.04.8327

15. Aydın M, Özen-Bekar E, Yılmaz-Gören Ş, Sungur MA. Hemşirelik öğrencilerinin toplumsal cinsiyet rollerine ilişkin tutumları. AlBÜ Sosyal Bilimler Enstitüsü Derg 2016;16:223-242.

16. Akın A. Toplumsal cinsiyet (gender) ayırımcılığı ve sağlık. Toplum Hekimliği Bülteni 2007;26:1-9.

17. Sezgin D. Toplumsal cinsiyet perspektifinde sağlık ve tıbbileştirme. Sosyoloji Araştırmaları Derg 2015;18:153-186.

18. Can Y. Attitude of the university students, family, gender roles and violence towards the women. IJSSER 2015;1:198-213.

19. Esen E, Soylu Y, Siyez DM, Demirgürz G. Üniversite öğrencilerinde toplumsal cinsiyet algısının toplumsal cinsiyet rolü ve cinsiyet değişkenlerine göre incelenmesi. E-Uluslararası Eğitim Araştırmaları Derg 2017;8:46-63.

20. Öngen B, Aytaç S. Üniversite öğrencilerinin toplumsal cinsiyet rollerine ilişkin tutumları ve yaşam değerleri ilişkisi. Sosyoloji Konferansları 2013;48:1-18.

21. Özaydınlık K. Toplumsal cinsiyet temelinde Türkiye'de kadın ve eğitim. Sosyal Politika Çalışmaları Dergisi 2014;33:93-112.

22. T.C. Aile ve Sosyal Politikalar Bakanlığı. Türkiye'de kadına yönelik aile içi şiddet araştırması. Ankara: Elma Teknik Basım Matbaası; 2015.

23. Uzun Z, Erdem S, Güç K, Safak-Uzun AM, Erdem E. Toplumsal cinsiyet algısı ve toplumsal cinsiyet rollerine eğitimin etkisi: Deneysel bir çalışma. JHS 2017;14:678693.

24. Dielissen PW, Verdonk P, Bottema BJ, Lagro-Janssen TL. Evaluating the teaching of gender-specific medicine in postgraduate training for general practitioners. J Eval Clin Pract 2009;15:1226-1229. https://doi.org/10.1111/ j.1365-2753.2009.01183.x

*Bu çalışmanın bir kısmı 12-15 Nisan 2018 tarihlerinde Antalya'da düzenlenen 15. Adli Bilimler Kongresi'nde sözel bildiri olarak tebliğ edilmiştir.

*Araştırmamız için Pamukkale Üniversitesi Girişimsel Olmayan Klinik Araştırmalar Etik Kurulu'ndan 17.01.2018 tarih ve 60116787020/4292 sayılı izin yazısı alınmıştır. 